\title{
Energy performance of a production system of eucalyptus
}

\author{
$\overline{\text { Thiago L. Romanelli }^{1} \& \text { Marcos Milan }}{ }^{1}$
}

\begin{abstract}
Maximizing yields is opposed to the goal of minimizing the use of inputs. In the context of system rationalization, the addition of non-economic parameters in the decision making and the magnitude of eucalyptus plantation in Sao Paulo State, Brazil led to this study. The objective was to establish the flows and to evaluate the performance of energy transformations on eucalyptus production. The evaluated system presented three alternatives of soil acidity management: lime, ash and sludge application. The applied indicators were energy return on investment, energy intensity and energy balance, which meant, respectively, the return over energy investment, the energy content of biomass and the energy obtained per area. For the basic scenario, lime, $E_{R 0 ।}$ was $58.5 \mathrm{MJ} \mathrm{MJ}^{-1}$, energy intensity was $124.7 \mathrm{MJ} \mathrm{m}^{-3}$, and the energy balance was $2120.7 \mathrm{GJ} \mathrm{ha}^{-1}$. The required energy was larger when ash $(5.2 \%)$ and sludge $(57.2 \%)$ were used. The main inputs were, in order, fuel, fertilizers, herbicide and lime. Harvesting was the main operation $(56.7 \%)$, followed by subsoiling. Fuel in harvesting, fertilizers and lime summed $79.6 \%$ of the total energy. The sensitivity of the system showed that the material used to control soil acidity had more effect on the energy demand (up to $+57.4 \%$ ) than the suggested scenarios $(-5.3 \%$ when the field efficiency was increased).
\end{abstract}

Key words: sustainability, environmental analysis, $E_{R O}$, energy balance

\section{Desempenho energético de uma produção de eucalipto}

\section{RESU MO}

0 contexto da racionalização dos sistemas de produção, a inserção de parâmetros não-econômicos na tomada de decisão e a magnitude do cultivo de eucalipto, no Estado de São Paulo, Brasil, nortearam este estudo, cujo objetivo foi estabelecer os fluxos e o desempenho das transformações energéticas de um sistema de produção de eucalipto. 0 sistema avaliado apresentou três alternativas de manejo de acidez do solo: calcário, cinzas e biossólido. Os indicadores utilizados foram 0 retorno de energia sobre energia investida, intensidade e balanço energéticos, que representam, respectivamente, a taxa de retorno de energia obtida, a energia contida na biomassa e a energia obtida por área. Para 0 cenário básico, calcário, o retorno de energia sobre energia investida foi de $58,5 \mathrm{MJ} \mathrm{MJ}{ }^{-1}$, a intensidade energética da biomassa $124,7 \mathrm{MJ} \mathrm{m}^{-3}$ e o balanço de energia foi $2120,7 \mathrm{GJ} \mathrm{ha}^{-1}$. A energia demandada foi maior com cinzas $(5,2 \%)$ e biossólido $(57,2 \%)$. 0 s principais insumos foram, em ordem decrescente: combustível, fertilizantes, herbicida e calcário. A colheita é a principal operação $(56,7 \%)$, seguida da subsolagem. 0 combustível gasto na colheita mais fertilizantes e calcário correspondem a 79,6\% da energia necessária. A sensibilidade do sistema mostrou que o material de controle de acidez do solo causa maiores efeitos na demanda de energia (até $+57,4 \%$ ) que os cenários sugeridos $(-5,3 \%$ com acréscimo da eficiência de campo).

Palavras-chave: sustentabilidade, análises ambientais, balanço de energia 


\section{INTRODUCTION}

Silviculture systems are economic and thermodynamic units, subject simultaneously to constraints of profit and physics laws. So, for planning and assessing forestry operations, both economic and non-economic factors must be considered, needing a systemic view (Tellarini \& Caporali 2000). Besides the studies dealing with economical and environmental issues (Raniusa et al., 2005; DiazBalteiro \& Rodriguez, 2006), one can find information about the energy approach on biomass and bioenergy sources (Chavanne \& Frangi, 2008; Pimentel \& Patzek, 2005; Pimentel et al., 2005; Ozkan et al., 2004) but the latter has been neglected by governmental policies. Through the 20th century, forestry and agriculture developed their yields through the increase use of energy, whose main source has been oil - a low entropy and non-renewable source (Ferraro Júnior, 1999). But this dependence on finite resources causes social, economic and environmental concerns. After a certain level, there are neither technical nor economic reasons for the field management to be intensified, regarding the output result due to the higher use of inputs (fertilizer etc.). Thus, there are conflicting requirements in trying to reach higher yields from a limited agricultural area through the minimum use of energy embodied in the inputs. This conflict can be diminished through the analysis of the interaction between crop and the energy applied in its management. The evaluation of how production systems demand and supply energy is vital (Romanelli \& Milan, 2005). Energy analyses establish flows, identify the total demand, the energy balance and the energy return on the invested energy $\left(\mathrm{E}_{\mathrm{ROI}}\right)$, as well as the energy embodied (intensity) in a product or service (Siqueira et al., 1999; Teixeira et al., 2005). Energy balance refers to the net energy gain per area while $\mathrm{E}_{\mathrm{ROI}}$ refers to the ratio of energy made available by the required energy in a process and it can be understood as "energy profitability" (Hall, 2004; Hammerschlag, 2006). Energy intensity is the energy embodied directly and indirectly per unit of the obtained product. One considers as input energy not only the applied sources (electricity, fuels), but also the energy embodied in input production and services. Angelini et al. (2005) evaluated energy flows in a field of Giant Reed (Arundo donax L.) considering different planting densities and fertilizer applications. The use of industrialized fertilizer improved the energy yield in a smaller magnitude than the required energy ( $15 \%$ versus $350 \%$ ). The fertilizer application and the denser planting provided the higher net energy gain (output - input), which indicates the amount of energy made available; but it had an opposite effect on the energy return on investment (output/input), which indicates the efficiency of obtaining energy regarding the energy consumed. Considering the search for sustainability in production systems, the insertion of non-economic parameters in the decision making and the magnitude of eucalyptus (Eucalyptus spp.) in Sao Paulo State, Brazil, this study aimed to establish energy flows and performance within a production system of eucalyptus.

\section{MATERIAL AND METHODS}

This study was developed through the following steps: 1) determination of the energy flows of a production system of eucalyptus in Sao Paulo state, Brazil; 2) evaluation of its performance using indicators such as energy balance, energy return on investment and energy intensity; 3) use a proposed algorithm to determine these indicators for a basic scenario (lime applied to adjust the soil acidity) and two alternative scenarios, which used ash and sludge instead of lime. The evaluation of the energy flows considered the fuel consumption, the machinery depreciation, the labor and the inputs directly applied in each mechanized operation performed. The mechanized operations were performed in the following sequence: lime application; subsoiling (plus fertilizer and pesticide application); furrowing; planting; irrigation; spraying (herbicide); fertilizer application (14-00-15 in the $3^{\text {rd }}$ month); spraying (herbicide); fertilizer application ( $\mathrm{KCl}$ in the $8^{\text {th }}$ month); spraying (herbicide); fertilizer application (14-00-15 in the $2^{\text {nd }}$ year); and harvesting. Ant combat and re-planting are operations that are performed according to the need and they were considered in this study.

Through the analysis of energy flows, one can establish the energy flows, identify the total demand, and determine the energy performance that can be reflected by the net gain and also by the ratio of energy made available regarding the energy invested. The indicators used to evaluate this performance are: energy balance $\left(\mathrm{E}_{\mathrm{B}}\right), \mathrm{E}_{\mathrm{ROI}}$ (energy return on investment) and energy intensity $\left(\mathrm{E}_{\mathrm{I}}\right) . \mathrm{E}_{\mathrm{B}}$ refers to the net energy gain per area while $\mathrm{E}_{\mathrm{ROI}}$ refers to the ratio of energy made available by the required energy in a process and it can be understood as "energy profitability". $E_{I}$ is the embodied energy per unit of the obtained product. $\mathrm{E}_{\mathrm{I}}$ is an important indicator for products which have no energetic use (e.g.: fiber). These indicators are determined through the energy input $\left(\mathrm{E}_{\mathrm{IF}}\right)$ and output $\left(\mathrm{E}_{\mathrm{OF}}\right)$ flows. For the $\mathrm{E}_{\mathrm{B}}$ to be determined (Eq. 1), the energy input flow $\left(\mathrm{E}_{\mathrm{IF}}\right)$ is subtracted from the output flow $\left(\mathrm{E}_{\mathrm{OF}}\right)$, resulting in the net gain per area.

Some authors refer to the energy balance as the ratio of energy made available and that required by a production system (Siqueira et al., 1999; Teixeira et al., 2005). However, in this study for this ratio the term $\mathrm{E}_{\mathrm{ROI}}$ (Eq. 2) was adopted (Hall, 2004).

$$
\begin{aligned}
& \mathrm{E}_{\mathrm{B}}=\mathrm{E}_{\mathrm{OF}}-\mathrm{E}_{\mathrm{IF}} \\
& \mathrm{E}_{\mathrm{ROI}}=\mathrm{E}_{\mathrm{B}} / \mathrm{E}_{\mathrm{IF}}
\end{aligned}
$$

where:

$$
\begin{aligned}
E_{B} & - \text { energy balance, } M J h^{-1} \\
E_{I F} & - \text { energy input flow, } \mathrm{MJ} \mathrm{ha}^{-1} \\
E_{\mathrm{OF}} & - \text { energy output flow, } \mathrm{MJ} \mathrm{ha}^{-1} \\
\mathrm{E}_{\mathrm{ROI}} & - \text { energy return on investment, } \mathrm{MJ} \mathrm{MJ}^{-1} 2
\end{aligned}
$$

\footnotetext{
${ }^{2} \mathrm{MJ} \mathrm{MJ}^{-1}$ was considered as the EROI measure. This consideration is due to the recognition of some authors of different energy quality regarding their entropy level and origin. If this consideration was not done, EROI could be non-dimensional.
} 
Considering the possibility of the harvested biomass not being used for energetic purposes, it is reasonable to relate the product obtained and the energy input in the production system. This is indicated by the energy intensity (EI), Eq. 3.

$$
\mathrm{E}_{\mathrm{I}}=\mathrm{E}_{\mathrm{IF}} / \mathrm{Y}
$$

where:

$$
\begin{aligned}
& E_{I} \text { - energy intensity, } \mathrm{MJ} \mathrm{m}^{-3} \\
& \mathrm{Y} \text { - yield, } \mathrm{m}^{3} \mathrm{ha}^{-1}
\end{aligned}
$$

The algorithm used to determine the material flow of inputs indirectly applied in the mechanized operations was developed by Romanelli (2007) (Figure 1).

It starts $(1)^{3}$ with the data input about the planted forest (2), applied labor (3) and the mechanized operations (4). The mechanized operations set covers implements (5) and the fleet ${ }^{4}(6)$, as well as the prescription of agricultural inputs (8). Soil condition (7) affects the traction demand (14). The data about the forest (9) (tree volume, average tree height and debarking during harvesting) determine the processing capacity, $\mathrm{m}^{3} \mathrm{~h}^{-1}$ (19). The ratio of processing capacity and yield $(10), \mathrm{m}^{3} \mathrm{ha}^{-1}$, provides the operational field capacity $\left(\mathrm{F}_{\mathrm{C}}\right)$ for harvesting $(20)$, ha $\mathrm{h}^{-1}$. In this case, harvesting $F_{C}$ is not based on width, speed or on the work

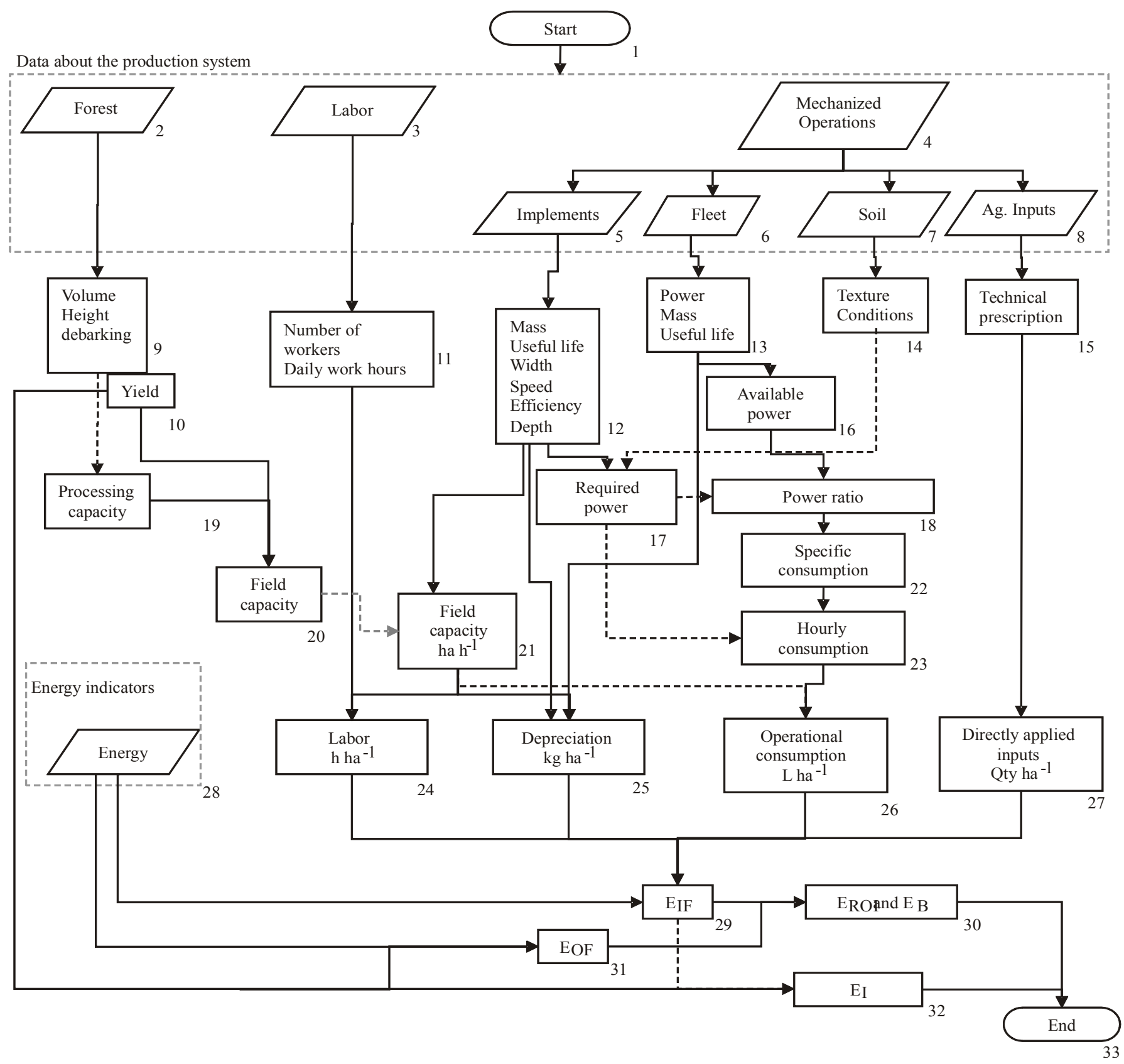

Figure 1. Algorithm developed to determine energy flows (Romanelli, 2007)

\footnotetext{
${ }^{3}$ Numbers between brackets indicate steps in the algorithm presented in Figure 1.

${ }^{4}$ Fleet here considered approaches self-propelled machines, such as tractors, harvesters, self-propelled sprayers.
} 
efficiency as in the other operations (21). Harvesters present processing capacity and the forest conditions determine the operation efficiency. Some studies present specific data for subsystems that are part of harvesting (Souza et al., 2004). The data on implements (12) and fleet (13) are mass, useful life, work width and speed, work efficiency and depth (soil tillage). Mass and useful life provide the physical depreciation of the machinery (25). Width, speed and field efficiency determines field capacity (21). Depth and soil condition (14) affect the power requirement (17). The power of the fleet (6) determines available power (16). The ratio (18) between required (17) and available power (16) determines the specific fuel consumption (22). The specific fuel consumption and the required power (17) determine the hourly fuel consumption $\left(\mathrm{L} \mathrm{h}^{-1}\right)$ (23), which related to the field capacity, provides the operational consumption ( $\mathrm{L} \mathrm{ha}^{-1}$ ) (26). One must emphasize that fuel consumption may vary due to the tractor features such as tire type, weight and work speed (Lopes et al., 2003).

The labor data - number of workers and daily work period (11) - related to the $\mathrm{F}_{\mathrm{C}}(21)$ determines the human labor per area (24). Since application rate of agricultural inputs are determined by technical prescription (15), the quantity of inputs (volume, mass, units) per area is provided directly (27). Multiplying each variable, labor (24), material depreciation (25), fuel (26) and inputs (27) by their respective energy index (28) it is possible to determine the energy input of each variable in the production system. Summing the individual contributions provides the energy input flow $\left(\mathrm{E}_{\mathrm{IF}}\right)$ (29). The energy indices used are found in references (Ulbanere \& Ferreira, 1989; Ferraro Júnior, 1999; Oliveira Júnior \& Seixas, 2006; Serra et al., 1979; Pimentel, 1980; Doherty, 1995). The multiplication of the energy content (28) of wood and yield (10) provides the energy output flow $\left(\mathrm{E}_{\mathrm{OF}}\right)$. $\mathrm{E}_{\mathrm{ROI}}$ and energy balance $\left(\mathrm{E}_{\mathrm{B}}\right)(30)$ are determined by the input (29) and output flows (31). The input flow (29) and yield (10) indicate the energy intensity (32) of the harvested biomass. After the determination of these indicators the use of this algorithm is ended (33).

The base scenario (lime) was the production system evaluated. The two alternatives (ash and sludge) regarding the soil acidity adjustment were also analyzed. In order to analyze the variables which affect more the results, one used the sensitivity analysis. Variables considered critical were selected and their initial values were changed in $10 \%$. Thus, the effect in other indicators could be measured. This technique was applied in the mechanized system management by Romanelli $\&$ Milan (2005). Through this analysis, improvements can be made in the sustainability of forestry production. Changes in the uses of labor, agricultural inputs, machinery and in the machinery management were suggested to be compared in the base scenario (lime as soil acidity corrector). The base scenario was changed in: $10 \%$ more field efficiency $\left(+\mathrm{F}_{\mathrm{E}}\right) ; 10 \%$ less used power $\left(-\mathrm{P}_{\mathrm{oW}}\right) ; 10 \%$ more useful life $\left(+\mathrm{U}_{\mathrm{L}}\right) ; 10 \%$ less labor $\left(-\mathrm{L}_{\mathrm{ab}}\right)$; and $10 \%$ less agricultural input $\left(-\mathrm{A}_{\mathrm{I}}\right)$, except the seedling use.

The scenario $+\mathrm{F}_{\mathrm{E}}$ represents the tractor-implement set or the self-propelled machine (e.g. combine) operating $10 \%$ more area per time. For this to be possible, it is necessary for some of the following management changes: increase work width, increase the work speed, to have a better plot shape and better planned maneuvers. The scenario $-\mathrm{P}_{\text {ow }}$ was suggested to evaluate the effects on the overall energy demand of the fuel consumption. The scenario $+\mathrm{U}_{\mathrm{L}}$ aimed to measure the improvement of a better maintenance and/or machinery durability. The scenario $-\mathrm{L}_{\mathrm{ab}}$ was suggested to check the effects of human labor use. And, finally, the scenario $-A_{I}$ explored the effect of better use of inputs through genetic developments, for instance.

\section{RESULTS AND DISCUSSION}

Through the model, represented by the algorithm, the material flow for every mechanized operation was determined (Table 1). The values of material flow were presented grouped by their type with their respective embodied energy. The product of these two values gives the energy input flow, which was calculated considering also the forest rotation period (energy input flow divided by time) for further comparison with other biomass production systems.

Table 1. Material flow of the base scenario and its energy evaluation

\begin{tabular}{|c|c|c|c|c|c|c|}
\hline \multicolumn{3}{|c|}{ Material flow } & \multirow{2}{*}{$\begin{array}{c}E_{E^{*}}^{*} \\
\text { MJ unit } 1\end{array}$} & \multicolumn{2}{|c|}{ Energy flows GJ ha-1 } & \multirow{2}{*}{$\%$} \\
\hline Inputs & unit ha-1 & unit & & & $\mathrm{yr}^{1}$ & \\
\hline Fuel & 529.2 & $\mathrm{~L}$ & $38.6^{1}$ & 20.4 & 2.92 & 56.3 \\
\hline Fertilizer* & 810.0 & $\mathrm{~kg}$ & $28.5^{2}$ & 8.3 & 1.19 & 23.0 \\
\hline Herbicide & 7.6 & $L$ & $327.0^{3}$ & 2.5 & 0.35 & 6.9 \\
\hline Lime & 1000.0 & $\mathrm{~kg}$ & $1.7^{2}$ & 1.7 & 0.24 & 4.6 \\
\hline Machines & 14.8 & $\mathrm{~kg}$ & $68.9^{1}$ & 1.0 & 0.15 & 2.8 \\
\hline Lubricant & 22.8 & $\mathrm{~L}$ & $38.6^{1}$ & 0.9 & 0.13 & 2.4 \\
\hline Seedling & 922.5 & unit & $0.8^{4}$ & 0.7 & 0.10 & 2.0 \\
\hline Labor & 231.4 & $\mathrm{~h}$ & $2.2^{5}$ & 0.5 & 0.07 & 1.4 \\
\hline Formicide & 1.0 & $\mathrm{~kg}$ & $184.7^{3}$ & 0.2 & 0.03 & 0.5 \\
\hline Water & 5556.0 & $\mathrm{~kg}$ & $0.0^{6}$ & 0.0 & 0.00 & 0.1 \\
\hline Total input & & & & 36.2 & 5.17 & 100.0 \\
\hline \multicolumn{7}{|l|}{ Output } \\
\hline Biomass & 290.5 & $\mathrm{~m}^{3}$ & 7425.0 & 2157.0 & 308.1 & \\
\hline
\end{tabular}

${ }^{*} \mathrm{E}_{\mathrm{E}}$ is the energy indicator of the energy directly and indirectly expended for obtaining or producing a good or service.

* Fertilizers grouped: $260 \mathrm{~kg}$ of 06-30-10 (2308.8 MJ ha-1), $400 \mathrm{~kg}$ of 14-00-15 (4960.0 MJ ha-1) and $150 \mathrm{~kg}$ of $\mathrm{KCl}\left(1078.5 \mathrm{MJ} \mathrm{ha}^{-1}\right)$.

${ }^{1}$ Ulbanere \& Ferreira (1989); ${ }^{2}$ Ferraro J únior (1999); ${ }^{3}$ Pimentel $(1980) ;{ }^{4}$ Oliveira J únior \& Seixas (2006); ${ }^{5}$ Serra et al. (1979); ${ }^{6}$ Doherty (1995).

The $\mathrm{E}_{\mathrm{IF}}$ was $36.2 \mathrm{GJ}^{-1}$ while the $\mathrm{E}_{\mathrm{OF}}$ was $2157.0 \mathrm{GJ}^{-1}$. So, the resulting $\mathrm{E}_{\mathrm{ROI}}$ was $58.5 \mathrm{MJ} \mathrm{MJ}^{-1}\left(8.4 \mathrm{MJ} \mathrm{MJ}^{-1} \mathrm{yr}^{-1}\right.$ for the annualized index). The $\mathrm{E}_{\mathrm{B}}$, which evaluates the net energy provided, was $2120.7 \mathrm{GJ} \mathrm{ha}^{-1}\left(303.0 \mathrm{GJ} \mathrm{ha}^{-1} \mathrm{yr}^{-1}\right)$ and the $\mathrm{E}_{\mathrm{I}}$ of the harvested biomass was $124.7 \mathrm{MJ} \mathrm{m}^{-3}$.

Although these numbers give the impression that eucalyptus is an efficient energy source, one must highlight that this analysis only approaches the inputs acquired in the market, not considering the soil, climate and hydric conditions that propitiates the presented productive potential. Considering the average sunlight in the region (3.91 GJ ha ${ }^{-1} \mathrm{~s}^{-1}$ ) through seven years, the total solar energy applied would be $8.56 * 10^{5} \mathrm{GJ}$, which represents $2.36 * 10^{5}$ times more energy than that pre- 
sented in all agricultural inputs or 397 times more energy than the contained in the calorific power of the harvested wood. There are methodologies just as energy synthesis that approach the environmental contribution (Cavalett et al., 2006; Pizigallo et al., 2008; Romanelli et al., 2008), but since these production means are free they are not taken into account in the energy flow determination.

The values obtained, considering the incident solar energy, agree with the second law of thermodynamics. Most authors, when discussing energy sources and renewable energy, do not mention that there is no energy generation such as it seems by observing data that exclude solar energy. What really exists is the energy availability, through energy transformations and their intrinsic losses.

The net energy made available $\left(\mathrm{E}_{\mathrm{B}}\right)$ and the energy "profitability" $\left(\mathrm{E}_{\mathrm{ROI}}\right)$ are both important for an energy source to be evaluated. But, in both indicators, the time spent on making the energy available is not considered. Relating these indicators with the period demanded for the forest to be harvest, one can obtain the annualized indicators, which allow the comparison of different production systems that surpass a one-year period. On the other hand, the annualized indicators would over-estimate annual crops which are grown in the better weather seasons that are not kept throughout the whole year.

For the use of the developed algorithm and its results to be validated; one looked for data available in the references. Either the energy intensity of biomass (Figure 2A) or the input energy (Figure $2 \mathrm{~B}$ ) were used in this comparison. The

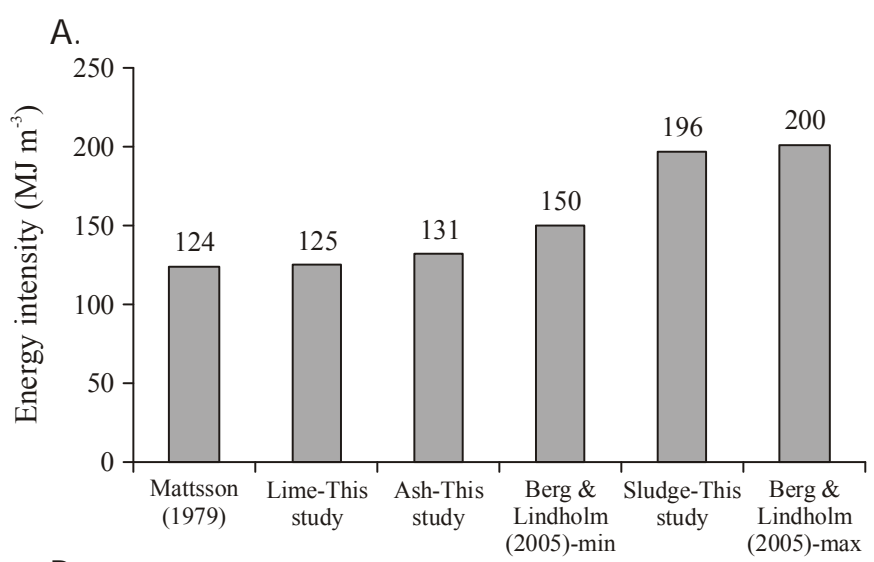

B.

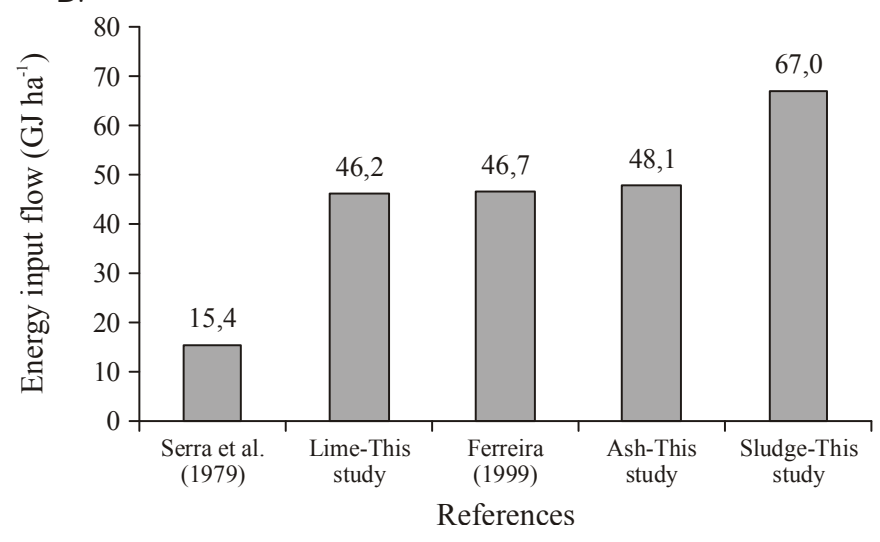

Figure 2. Energy intensity and energy input from different production systems results of the alternatives lime, ash and sludge, are between the lowest (Mattsson, 1979) and the highest values (Berg \& Lindholm, 2005). Although $61.6 \%$ the amplitude of these values are considerable (from 123.8 to $200 \mathrm{MJ} \mathrm{m}^{-3}$ ) the 26 years of difference between these papers shows the difference on soil use in Sweden where both works were carried on.

The base scenario had the energy intensity $0.7 \%$ above the minimum found (Mattsson, 1979) and $16.9 \%$ and $37.7 \%$, respectively, below the minimum and maximum limits found in Berg \& Lindholm (2005). The algorithm presented results within the range provided by the references. The sludge scenario is closer to the maximum found, although it represents a tropical production system. But this high energy content is due to the methodology which establishes the energy indicator according to the sludge's NPK content.

Comparing the energy input of production systems, the results from the suggested algorithm are closer to the most recent reference (Ferreira, 1999). The higher amount of energy, demanded in the current production systems, is due to the intense adoption of agricultural inputs and machinery. Once more, the sludge scenario stood out from the others, with $39.3 \%$ more than the second most demanding (Figure 2). This is explained by its higher content of industrialized nitrogen (the most energetically intense nutrient) and by the amount applied per area $\left(7700 \mathrm{~kg} \mathrm{ha}^{-1}\right)$.

Besides lime, there is the possibility to use ash and sludge as a corrector of soil acidity by the production system evaluated their characteristics are on Table 2.

Table 2. Characteristics of alternative materials used for soil acidity adjustment

\begin{tabular}{ccccc}
\hline \multirow{2}{*}{ Item } & Quantity & Energy index & \multicolumn{2}{c}{ Energy input flow } \\
\cline { 4 - 5 } & kg ha-1 $^{-1}$ & MJ kg $^{-1}$ & MJ ha-1 & MJ ha $^{-1} \mathbf{~ y r}^{-1}$ \\
Ash & 3000.0 & 1.18 & 3540.0 & 505.7 \\
Sludge & 7700.0 & 2.91 & 22407.0 & 3201.0 \\
\hline
\end{tabular}

The embodied energy of the alternative materials for soil acidity adjustment was determined considering their NPK content. This estimative does not seem to be the most appropriated one since the NPK content may not represent the actual energy content of the material. This method only regards the avoidance of synthesis or extract the equivalent of nutrients. Although the alternative materials present more NPK content than lime, no difference on the fertilization planning is observed.

Due to the larger amount of alternative material applied to correct soil acidity, the input energy increased, making them less environmentally attractive, according to the adopted indicators (Table 3). The input energy was 5.7 and $57.2 \%$ higher for ash and sludge, respectively. The same differences were observed in the energy intensity comparison. Their $\mathrm{E}_{\mathrm{ROI}}$ indices were 95.0 and $63.1 \%$ of the base scenario's index. Energy balance had a decrease lower than $1 \%$ for both.

For a better comparison among the alternative uses of ash and sludge, an analysis in a larger scale should be done. When ash and sludge (or other residues to be discarded) are used, society avoids the demand for landfills, transport and 
Table 3. Comparison of alternative soil acidity adjustment

\begin{tabular}{|c|c|c|c|c|}
\hline Altematives & $\begin{array}{c}\text { Input Energy } \\
\text { MJ ha-1 }\end{array}$ & $\begin{array}{c}\mathbf{E}_{1} \\
\mathrm{MJ} \mathrm{m}^{-3}\end{array}$ & $\begin{array}{c}E_{\text {ROI }} \\
M M^{-1}\end{array}$ & $\begin{array}{c}E_{B} \\
\text { GJ } h^{-1}\end{array}$ \\
\hline Lime & 36234.5 & 124.7 & 58.5 & 2120.7 \\
\hline Ash & 38104.5 & 131.2 & 55.6 & 2118.9 \\
\hline Sludge & 56971.5 & 196.1 & 36.9 & 2100.0 \\
\hline
\end{tabular}

storage. So, these indirect benefits could be taken into account as energy flows in the determination of the most environmental friendly option.

Fuel and fertilizers are responsible for $79.3 \%$ of the demanded energy (around 75\% in the ash and sludge scenarios). Fuel was the main energy intense input with around three times more than fertilizers. Since fuel is an input indirectly applied, distinctly from fertilizers, seedlings etc., one highlights the importance of monitoring "how" the inputs are used and not only "how much" it is applied. Machinery management plays a vital role on monitoring how the assets are being used. It was chosen to treat fertilizers (06-30-10, 14-00-15 and $\mathrm{KCl}$ ) as one group, in which they represented $27.7 \%, 59.4 \%$ and $12.9 \%$ of the energy content within the group, respectively.

Data from the base scenario (Table 4) were used in order to detail the production system regarding its mechanized operations and inputs directly (agricultural inputs) and indirectly (fuel, depreciation and labor) applied. From the four production factors, fuel and agriculture inputs represent almost the whole energy demanded $(95.8 \%)$, getting the status of the most important for the search for environmental efficiency improvement. Regarding the mechanized operations, the harvesting is the most important by far. The magnitude of its values is due mainly to the low field capacity $\left(0.055 \mathrm{ha} \mathrm{h}^{-1}\right)$ which makes every hourly consumption to be multiplied by the 18.2 hours taken for a single hectare $\left(290.5 \mathrm{~m}^{3} \mathrm{ha}^{-1}\right)$ to be harvested.

Besides harvesting, fuel is important also in irrigation due to the use of a tank-truck to support the operation. Except for these operations, only the agricultural inputs directly

Table 4. Energy demand per operation and class of input

\begin{tabular}{lrrccr}
\hline \multirow{2}{*}{ Mechanized operation } & \multicolumn{5}{c}{ Energy Demand (\%) } \\
\cline { 2 - 6 } Lime appl. & Fuel & Depr. & Labor & Ag Input & Total \\
Subsoiling & 0.3 & 0.0 & 0.0 & 4.6 & 5.0 \\
Furrowing & 1.0 & 0.1 & 0.0 & 7.3 & 8.4 \\
Planting & 0.5 & 0.1 & 0.0 & 0.0 & 0.6 \\
Irrigation & 0.2 & 0.1 & 0.1 & 1.9 & 2.2 \\
Herbicide (1 ${ }^{\text {st) }}$ & 1.4 & 0.1 & 0.1 & 0.1 & 1.6 \\
Fertilizer appl. (3rd month) & 0.2 & 0.1 & 0.0 & 2.7 & 3.0 \\
Herbicide (2nd) & 0.3 & 0.0 & 0.0 & 5.1 & 5.4 \\
Fertilizer appl. (KCl) & 0.1 & 0.0 & 0.0 & 1.6 & 1.7 \\
Herbicide (3rd) & 0.4 & 0.1 & 0.0 & 3.0 & 3.4 \\
Fertilizer appl. (2 ${ }^{\text {nd }}$ year) & 0.1 & 0.0 & 0.0 & 1.6 & 1.7 \\
Harvesting & 0.4 & 0.1 & 0.0 & 8.6 & 9.0 \\
Ant combat & 51.0 & 2.2 & 1.0 & 2.4 & 56.7 \\
Re-planting & 0.0 & 0.0 & 0.1 & 0.5 & 0.6 \\
\hline Total & 0.5 & 0.0 & 0.1 & 0.1 & 0.7 \\
\hline
\end{tabular}

applied are in the list of the main energy demanders. Although pesticides present high energy indices ( 80 to $450 \mathrm{MJ} \mathrm{L}^{-1}$ ), little volume is applied per area, making them not an import energy demander. But, in a case of over dosage, although the energy-demand effect, serious environmental issues may be posed be toxicological effects.

The sensitivity analysis was performed as a way to quantify how much changes in the forest management would affect the energy efficiency. The energy input was the indicator chosen to be measured. All the scenarios were related according to Table 1 and, in each case, the suggested changes were evaluated through fixed $10 \%$ alterations in some production factors. The main result is that the choice of the material used to adjust soil acidity caused the higher difference in the energy efficiency. Within each alternative for soil acidity adjustment, the largest difference observed was $5.3 \%$ (Table 5). The choice of material reached up to $55.6 \%$ of difference.

Table 5. Energy demand in the proposed scenarios

\begin{tabular}{cccc}
\hline \multirow{2}{*}{ Scenarios } & \multicolumn{3}{c}{ Alternatives for Soil Acidity Adjustment } \\
\cline { 2 - 4 } & Lime & Ash & Sludge \\
Base & 100.0 & 105.1 & 155.6 \\
+ FE & 94.7 & 99.7 & 150.2 \\
-Pow & 99.9 & 105.0 & 155.5 \\
+ UL & 99.8 & 104.8 & 155.3 \\
-Lab & 99.9 & 104.9 & 155.4 \\
-Al & 96.0 & 100.6 & 146.1 \\
\hline
\end{tabular}

The higher improvement $(5.3 \%)$ in the energy performance was observed by the increase of field efficiency $\left(+\mathrm{F}_{\mathrm{E}}\right)$ and consequently, field work capacity. It was assumed that this improvement would not represent an increase in any other production factor (for instance: fuel). Through field efficiency the production factors indirectly applied (labor, machinery and fuel) are reduced per area since all of them are related to the field work capacity to be expressed in area. Some management options may make this suggestion possible, such as plot shape better planned to decrease the time on maneuvers. The second best improvement came from the reduction of the agricultural inputs $\left(-\mathrm{A}_{\mathrm{I}}\right)$ with a similar effect $(4.0 \%)$. For this to be possible, techniques such as localized fertilizer application (Pierce \& Nowark, 1999) present high potential to be implemented in forestry. The remaining scenarios did not change significantly the global efficiency of the production system. Thus, they would not pose as important factors to be addressed in the search of improvements on energy efficiency.

An important aspect to be emphasized about the sensitivities shown is that even little differences on efficiency can have substantial implications in the resource use efficiency. Although evaluated at the farm level or even stand level, one should keep in mind that forestry operations are performed in million of hectares. So, even slight improvements may represent a considerable value of fuel saved, for instance. 


\section{CONCLUSIONS}

1. The alternatives for soil acidity adjustment, ash and sludge, turn out to be less energetically efficient than lime.

2 . Within the classes of production factors, the agricultural inputs and fuel are the main determinants of the energy flow. For the efficiency of resource use to be improved, genetic material with less dependence on inputs may be adopted. The most energy demanding mechanized operations should be managed for fuel consumption to be reduced.

3. Regarding the operations, harvesting is the most energy demanding operation. However, this operation may present a high level of efficiency in its management. Besides harvesting, the operations in which fertilizer are applied posed as important energy demanders.

4. The sensitivity analysis indicated that the kind of material applied to adjust soil $\mathrm{pH}$ was more important than the suggested scenarios. Of all suggested scenarios, the highest improvement was in the increase of field efficiency, followed by reducing the use of directly applied inputs (fertilizer, pesticides etc.).

\section{ACKNOWLEDGMENT}

We acknowledge CAPES (Coordenação de Aperfeiçoamento de Pessoal de Nível Superior) for providing funds for this study and Suzano Cell and Paper Company.

\section{LITERATURE CITED}

Angelini, L. G.; Ceccarini, L.; Bonari, E. Biomass yield and energy balance of giant reed (Arundo donax L.) cropped in central Italy as related to different management practices. European Journal of Agronomy, v.22, n.4, p.375-89, 2005.

Berg, S.; Lindholm, E. L. Energy use and environmental impacts of forest operations in Sweden. Journal of Cleaner Production, v.13, n.1, p.33-42, 2005.

Cavalett, O.; Queiroz, J. F.; Ortega, E. Emergy assessment of integrated production systems of grains,pig and fish in small farms in the South Brazil. Ecological Modelling, v.19, n.2, p.205-224, 2006.

Chavanne, X.; Frangi, J. P. Le rendement énergétique de la production d'éthanol à partir de maïs. Comptes Rendus Geoscience, v.340, n.5, p.263-287, 2008.

Diaz-Balteiro, L.; Rodriguez, L. C. E. Optimal rotations on eucalyptus plantations including carbon sequestration. A comparison of results in Brazil and Spain. Forest Ecology and Management, v.229, n.1/3, p.247-258, 2006.

Doherty, S. J. Emergy evaluations and limits to forest production. Gainesville: University of Florida, 1995. 163p. Ph.D. Dissertation

Ferraro Júnior, L. A. Proposição de método de avaliação de sistemas de produção e de sustentabilidade. Piracicaba: ESALQ/ USP, 1999. 132p. Dissertação Mestrado

Ferreira, O. C. Análise exergética da agricultura. Economia \& Energia, v.3, n.12, p.12-18, 1999.
Hall, C. A. S. The myth of sustainability development - Personal reflection on energy, its relation to neoclassical economics and Stanley Jevons. Journal of Energy Resource Technology, v.126, n.2, p.85-89, 2004.

Hammerschlag, R. Ethanol's energy return on investment: A survey of the literature 1990 " Present Environmental Science \& Technology, v.40, n.6, p.1744-1750, 2006.

Lopes, A.; Lanças, K. P.; Furlani, C. E. A.; Nagaoka, A. K.; Castro Neto, P.; Grotta, D. C. C. Consumo de combustível de um trator em função do tipo de pneu, de lastragem e da velocidade de trabalho. Revista Brasileira de Engenharia Agrícola e Ambiental, v.7, n.2, p.382-386, 2003.

Mattsson, J. E. Energy of forest machines in Swedish forestry as a whole. In: Seminar on Energy Aspects of the Forest Industries, 1, 1979, Udine. Proceedings... Oxford: Pergamon Press, 1979. p.321-330.

Oliveira Júnior, E. D.; Seixas, F. Análise energética de dois sistemas mecanizados na colheita de eucalipto. Scientia Florestalis, v.70, p.49-57, 2006.

Ozkan, B.; Arcaoz, H.; Fert, C. Energy input-output analysis in Turkish agriculture. Renewable Energy, v.29, n.1, p.39-51, 2004.

Pierce, F. J.; Nowak, P. Aspects of precision agriculture. Advances in Agronomy, v.67, n.1, p.1-85, 1999.

Pimentel, D. Handbook of energy utilization in agriculture. Boca Raton: CRC Press, 1980. 475p.

Pimentel, D.; Hepperly, P.; Hanson, J.; Douds, D.; Seidel; R. Environmental, energetic and economic comparisons of organic and conventional farming systems. BioScience, v.55, n.77, p.573-582, 2005.

Pimentel, D; Patzek, T. W. Ethanol production using corn, switchgrass, and wood; Biodiesel production using soybean and sunflower. Natural Resources Research, v.14, n.1, p.65-76, 2005.

Pizzigallo, A. C. I.; Granai, C.; Borsa, S..The joint use of LCA and emergy evaluation for the analysis of two Italian wine farms. Journal of Environmental Management, v.86, n.3, p.396-406, 2008.

Raniusa, T.; Ekvallb, H.; Jonssona, M.; Bostdebt, G. Cost-efficiency of measures to increase the amount of coarse woody debris in managed Norway spruce forests. Forest Ecology and Management, v.206, n.1/3, p.119-133, 2005.

Romanelli, T. L. Sustentabilidade energética de um sistema de produção da cultura de eucalipto. Piracicaba: ESALQ/USP, 2007. 121p. Tese Doutorado

Romanelli, T. L.; Cohen, M. J.; Milan, M.; Brown, M. T. Emergy synthesis of intensive eucalyptus cultivation in São Paolo, Brazil. Forest Science, v.54, n.1, p.228-241, 2008.

Romanelli, T. L.; Milan, M. Energy balance methodology and modeling of supplementary forage production for cattle in Brazil. Scientia Agricola, v.62, n.1, p.1-7, 2005.

Serra, G. E.; Heezen, A. M.; Moreira, J. R.; Goldemberg, J. Avaliação da energia investida na fase agrícola de algumas culturas. Brasília: Secretaria de Tecnologia Industrial, 1979. $86 \mathrm{p}$.

Siqueira, R.; Gamero, C. A.; Boller, W. Balanço de energia na implantação e manejo de plantas de cobertura do solo. Engenharia Agrícola, v.19, n.1, p.80-89, 1999. 
Souza, A. P.; Minette, L. J.; Moreira, F. M. T.; Machado, C. C.; Silva, K. R. Análise do desempenho da máquina 'slingshot em subsistemas de colheita em florestas de eucalipto. Revista Brasileira de Engenharia Agrícola e Ambiental, v.8, n.2,3 p.316-320, 2004.

Ulbanere, R. C.; Ferreira, W. A. Análise do balanço energético para à produção de milho no Estado de São Paulo. Engenharia Agrícola, v.4, n.1, p.35-42, 1989.
Teixeira, C. A.; Lacerda Filho, A. F.; Pereira, S.; Souza, L. H.; Russo, J. R. Balanço energético de uma cultura de tomate. Revista Brasileira de Engenharia Agrícola e Ambiental, v.9, n.3, p.429-432, 2005.

Tellarini, V.; Caporali, F. An input/output methodology to evaluate farms as sustainable agroecosystems: an application of indicators to farms in central Italy. Agriculture, Ecosystems and. Environment, v.77, n.1/2, p.111-123, 2000. 